\title{
The Bokharan Deer in the USSR
}

\author{
A. G. Bannikov and L. V. Zhirnov
}

With a total population estimated at under 500, mostly living in forests that are constantly under threat of felling, the Bokharan deer or hangul is in serious danger of extinction. This is a red deer subspecies confined to the Turkmenistan-Afghanistan frontier region, and closely akin to the Kashmir hangul described in Oryx, December 1970. In this survey Professor Bannikov and Dr Zhirnov summarise what is known about it and its present status, and point to the urgent need for active protection measures.

The Bokharan hangul Cervus elaphus bactrianus is in danger of extinction and is now in IUCN's Red Data Book. In Russia it is also called the Bokharan deer, and the tugai deer - tugai is a complex of forests, bushes and meadows in the river valleys of desert areas. Although it is a well differentiated red deer subspecies, clearly distinguishable from others in the USSR, its relationship with other subspecies such as the Kashmir hangul C.e. hangul, with which it seems to be identical or very close, and C.e. affinis has not been cleared up.

\section{Description}

Of medium size and slightly smaller than the other subspecies, the Bokharan deer stands about $120 \mathrm{~cm}$ at the withers; the skull length is up to $390 \mathrm{~mm}$. Mature males can weigh $200-250 \mathrm{~kg}$. The body is a light yellowish-grey, the legs pale; the well developed mirror, of which the upper part is reddish, the lower white, is smaller than that of the other forms in the USSR. Lips and chin are a dingy white, and the antlers of medium size, usually with five tines, but occasionally six or even seven. The crown is very seldom formed; the two end tines usually form a fork.

\section{Former Range}

The dear inhabits the narrow belts of tugai forest usually found in river valleys. In the 19th century it occurred throughout the entire length of the Amu Darya and the lower Syr Darya rivers, as far south as the town of Tuktestan. At certain seasons some were in the northern Kizil-Kum, adjoining the Syr Darya, then covered with dense haloxylon forests, and occasionally they penetrated even to the lower Sary-Su (Bobrinsky, 1933). In the Amu Darya basin they came as far south as the upper limit of the forest, i.e. to the Pyandzh river and all the tributaries with large tugai stands, such as the Shirabad, Sukhan Darya, Kafirnigan and Vaksh. On the right bank of the Pyandzh they occurred from the lower Vakhsh to the Choubek district, and in the tugai forests along the Kizil- Su and Yakh-Su rivers. In northern Afghanistan they were widespread along the Kunduz and Tamekhan rivers, tributaries of the Amu Darya and the Pyandzh. On the Afghan side they penetrated as far as the Koukcha river, and may also have inhabited the tugai forests along the Murgab 


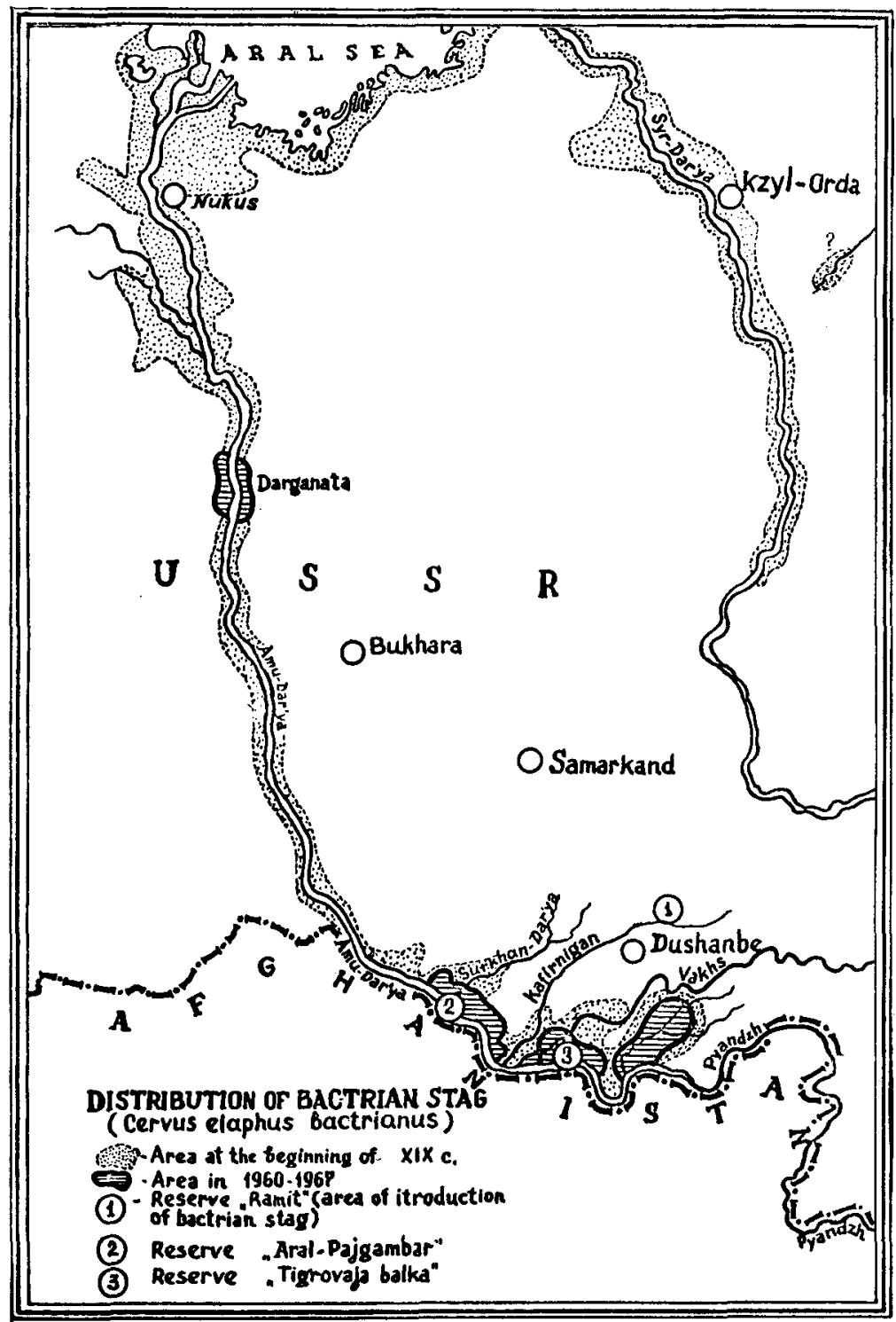

river* (Flyorov, 1935). But by the early years of this century they had been completely wiped out on the Syr Darya river, as a result of the destruction of the tugai forests - through cutting, cattle grazing and reed-burning - together with uncontrolled hunting; on the Amu

*In the remote past deer probably of the Caucasian type inhabited the areas along the rivers of Tedgen and Atrek, possibly coming in from Iran. 
Darya and Pyandzh rivers their habitat has contracted severely since the early 1930's.

By the middle 1950's they survived in only four areas - the Darganat reserve ${ }^{\dagger}$ and three places on the upper Amu Darya (the Pyandzh river). These three areas were:

1. In the lower Kizil-Su (from the north-western regions of Parkhar to the mouth of the Pyandzh and further east) from Parkhar to the confluence of the Pyandzh and Kizil-Su;

2. from the mouth of the Vakhsh river to Dgilikul, and from the confluence of the Vakhsh and the Pyandzh to the settlement of Pyandzh; and

3. along the Amu Darya - from its confluence with the Kafirnigan to the Tajikstan-Uzbekistan boundary (Chernyshov, 1958). In 1950 there were 50 in the forest of Khatyn-Rabat (Ishumin, 1961).

Since 1950 data collected by questionnaires and from expeditions to Turkmenistan and Tajikistan show that the areas have continued to shrink. By 1963-1970 the deer were known to be in the following areas (see map):

1. The middle course of the Amu Darya: $12-15$, singly or in small groups, in the tugai forests of the Darganata area* (Darganata district; Chardzhou region, Turkmenistan).

2. The upper Amu Darya and the Pyandzh:

a. about 90 animals, in the island reserve of Aral-Paygambar (2 on the map) on the Amu Darya (Termez district, Uzbekistan) in 1969 (A. Bannikov, 1969), where, in 1963, Ishunin reported about 70 (1967). Here a combination of a relatively large area (4000 hectares), well preserved tugai forests, and an island site within the frontier zone have contributed to their preservation;

b. about 250 in Tajikistan (along the Amu Darya and Pyandzh), which have probably remained within the 1950 boundaries.

Twelve deer set free in 1960-1961 in the Ramit gorge of the Gissar ridge (see 1 on the map) close to the tugai forests in the Sarday-miyona valley, had bred and increased to about 50 by August 1966, according to two workers in the reserve, L. Dodosyan and M. Gulyayeva; by 1970 there were 65 (Sapozhnikov). Unfortunately the very broken terrain makes it impossible to enlarge this area. Precise population data for the deer in the last century are not available, and the table is based on data collected since 1930 .

In the upper course of the Amu Darya, in the Darganata tugai forests the deer population numbered 60 in the early 1940's (Klyushkin, 1949), and increased up to 100 (Klyushkin, 1954). But $\dagger$ The Darganat reserve only existed from 1941 to 1949 . In 1941, according to the survey data the population numbered about 60 (Klyushkin, 1949).

*According to the data collected by A. Mambetdgumayev in 1963-1964 some individual animals (usually one male or one female with calves) were found in the area to the north of Nukus, in the tugai forests of Kizil-Kala and Zhinishke-Tugai (Mambetdgumayev, 1967). 


\section{Population Estimates and distribution 1963-1970}

Areas (republic, district)

1

$\begin{array}{cc}\text { Year } & \text { Numbers } \\ 2 & 3\end{array}$

3
Source

4

Turkmen SSR

1. Darganat district,

Chardgou region - tugai

forests on the Amu Darya

1963

10

N. Ishadov (1965)

2. Darganat district - tugai

forests on the Amu-Darya

(Djikerbent, Karaaygyr,

Darganata, Gorelde)

1966

1969

13

c.15

A. Khakyev

U. Mamaev (1969)

Uzbek SSR

1. Termez district, Sukhan

Darya region - the island of

Aral-Paygambar ( 2 on the map)

$\begin{array}{lll}1963 & 70 & \text { G. Ishunin (1967) } \\ 1969 & 90 & \text { A. Bannikov (1969) }\end{array}$

Tajik SSR

1. The lower Vakhsh -

Tigrovaya Balka reserve

1964-

1965

c.100(93)

G. Sapozhnikov (1965,

1968

c.150(144)

1968)

2. Tugai forests on the rivers

of Kizil-Su and Pyandzh;

vicinity of Parkhar (Parkhar district)

1966

c.50

Questionnaires

3. Tugai forests on the Pyandzh (vicinity of the Kishlak of Bogaran)

1966

10

Questionnaires

4. Gissar ridge, the Ramit

reserve, Ordgonikidzebad

district (deer were

acclimatised in 1960)

$\begin{array}{lll}1966 & 50 & \begin{array}{l}\text { M. A. Gulyayeva, } \\ \text { L. Dodosyan }\end{array} \\ 1970 & 65 & \text { G. Sapozhnikov }\end{array}$

large new settlements in this part of the valley, starting in the early 1940 's, accelerated the destruction of the tugai forests to bring new land under cultivation, and the deer population decreased sharply. In the late summer of 1966 a special survey in the Amu Darya valley, from the settlement of Sadyvar (Darganata district) to the station of Khalif (Charshangin district) showed only 16 deer in all the tugai forests, which means that only individual animals and small groups have survived. Such a small population, which can hardly increase, is likely to disappear in two to three years. Moreover, the Tuya-Murgan dam, planned for the next five-year period, will flood all the tugai forests in the Darganata district. In the circumstances the Turkmen SSR's Department of Hunting and Reservations has suggested moving 


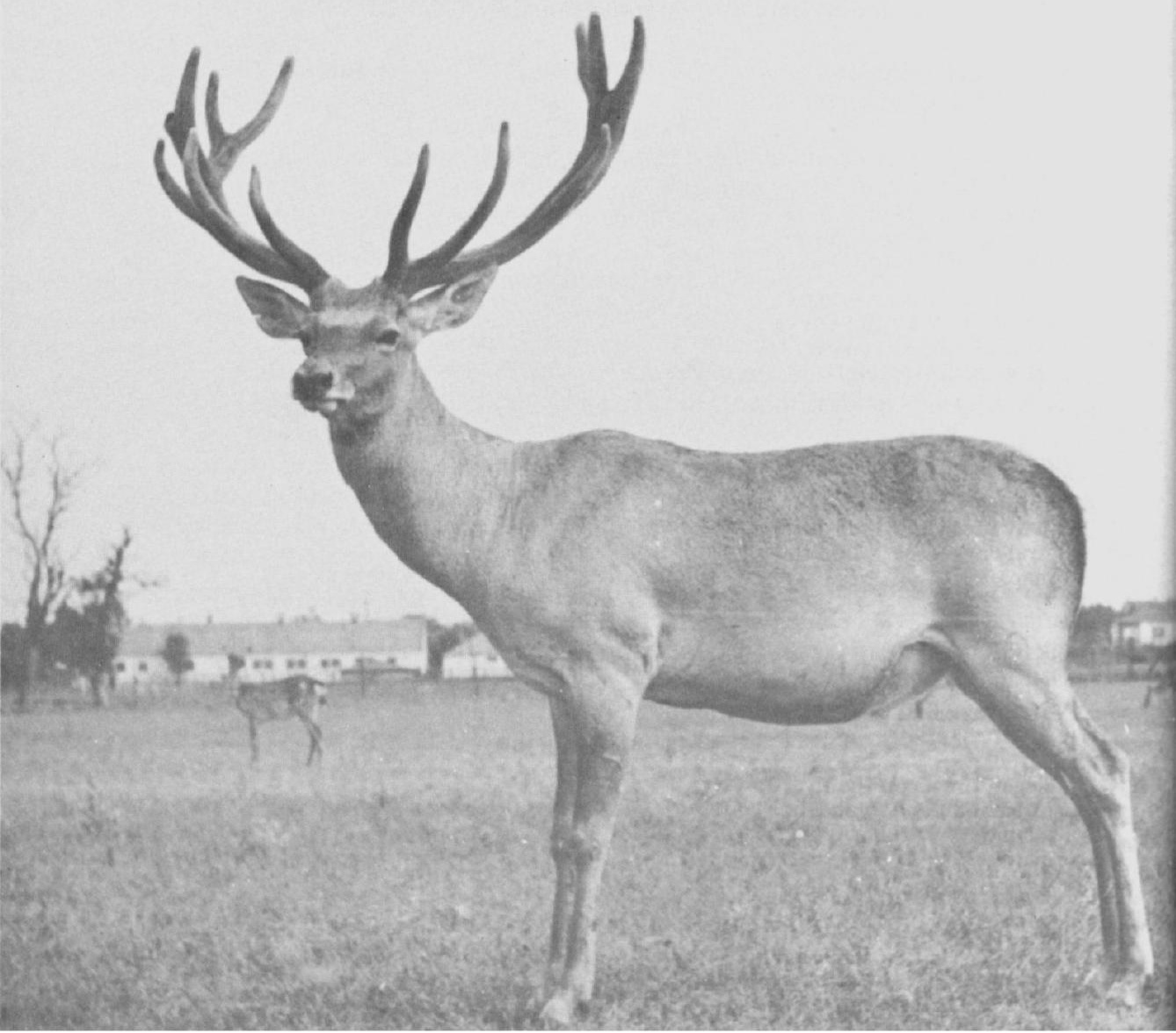

BACTRIAN STAG above

Right In the Ramit Nature Reserve, Tadzhikistan. V.A. Ognev 


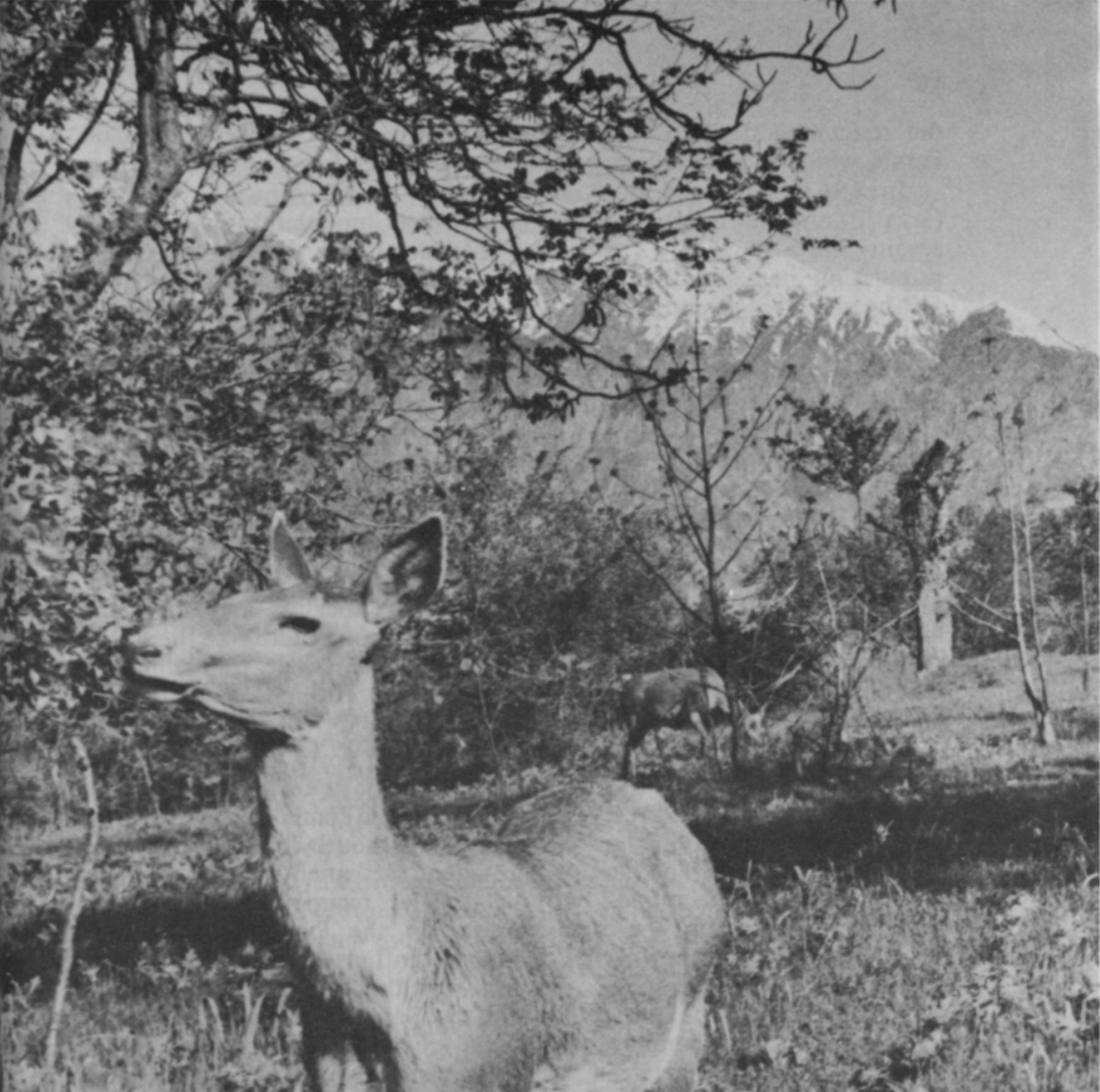

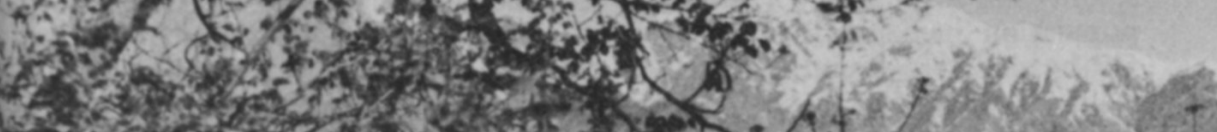

-

toring

a

H - M M

1)

(a)

How

( $)$

a 10 .

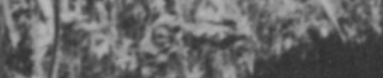

anse

inges

x.

$x^{2}+1$

$=x+2$

$x+400$. Thon

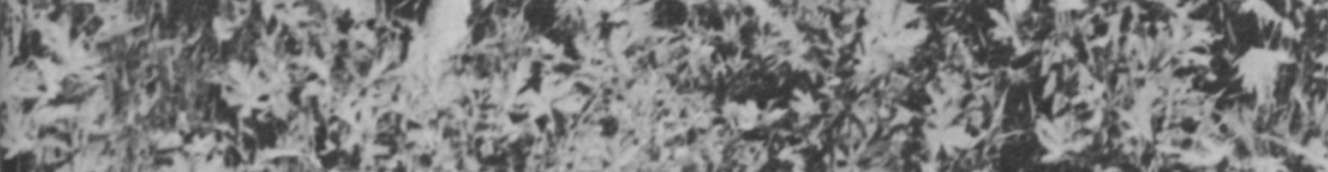

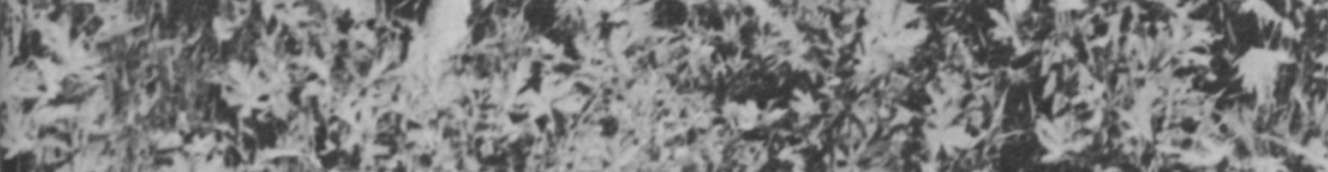

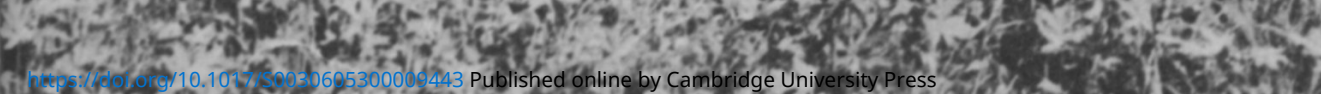

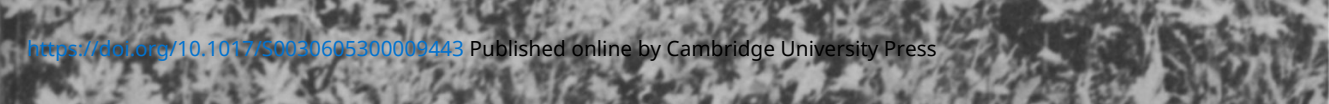


the remaining deer to the tugai land to the south of the station of Farab, which is suitable for a reserve.

In 1963 the island of Aral-Paygambar in the Amu Darya River (area 2 on the map) had the largest deer population with about seventy heads, and a survey in March 1967 showed that this population had stabilised. In 1962 three groups of animals, each of 5-7 heads, were found in the tugai forests between Stary Termez and Kelif (Ishunin, 1967), so the total for the area is not more than 100.

The Best Tugai Forests

The tugai forests on the Amu Darya and Pyandzh are the best preserved in Tadzhikistan. The largest deer population here is to be found on the lower Vakhsh river - in the Tigrovaya Balka reserve and the tugai forests to the south of it, along the Vakhsh and Pyandzh rivers. However this population too is in continuous decline. In 1949 there were 222 in Tigrovaya Balka (Chernyshov, 1958); at the end of the 1950's these had increased to 500-600 (Chernyshov, 1958); but in the 1960's numbers decreased catastrophically, and in 1965 members of the Commission for Preservation of Wildlife at the Tajik Academy of Sciences put the number at 93, although, following our visit in 1966, we decided that there were over 100, and Sapozhnikov in 1968 put the figure at 144.

According to B. V. Vorobyev, who worked for a long time in the area of the lower Vakhsh and Pyandzh Rivers, there is considerable population in the tugai forests on the left (Afghan) bank of the Pyandzh and on many islands on the Vakhsh from its mouth to the settlement of Nizhny Pyandzh. The lack of permanent settlements on the Afghan side of this area, coupled with a frontier regime, has helped to preserve the deer in the tugai forests on the Pyandzh river, but destructive autumn hunting in Afghanistan inflicts heavy losses as also does the Afghan practice of burning the reed. This frontier population should be protected, and the Soviet Union and Afghanistan should take common protective measures, since there is a constant exchange between the left- and right-bank populations during migrations when the rivers are in flood.

The second large concentration in Tadzhikistan is in the lower Kizil-Su and the adjoining tugai forests along the Pyandzh river (Parkhar district, Tajik SSR), where there are about 60 in groups of five to seven animals, according to the data obtained in 1966 from questionaires. Thus, in 1965-1967 the population in Tadzhikistan was 250-300 animals, and the total population in the USSR today is only 300-400; outside the Tadzhikistan territory (Turkmenistan and Uzbekistan) there are little more than 100 head. Even though these may be underestimates, since the deer live in dense forests and counting is difficult, the figures give a present total population of $400-500$ animals, all on the verge of disappearing because of the continual deterioration of the habitat by destruction of the tugai forest. The situation demands that urgent measures should be taken to protect and rehabilitate this deer both in the USSR and Afghanistan. 


\section{Habitat}

Tugai forests are the deer's principal habitat, where they feed, shelter and rest, mate and calve. In the middle Amu Darya (Darganat) they also inhabit flood-lands covered with brakes of thorny salt tree Halimodendron holodendron, poplar Populus pruinosa, Russian wild olive Elaeagnus angustifolius, tamarisk Tamarix sp. and reed Phragmites communis. In summer they stay in the tugai areas, where herbaceous plants dominate, but in winter they prefer woody and shrubby vegetation (Klyushkin, 1949, 1954). A. Mambetdgumayev (1961) defines six stages in their life in the tugai forests in the middle Amu Darya.

Along the Kafirnigan river they inhabit areas in the tugai forests covered with cane brakes and sparse Russian wild olive trees with intermittent meadow vegetation. On the lower Vakhsh and Pyandzh they prefer valley forests consisting of heterophyllous poplar and Russian wild olive. In spring they can often be found in the tamarisk brakes, where they find feed and good shelter. In winter and even more in early spring they periodically leave the tugai forests and feed in the adjoining desert lands, on luxuriant ephemerals such as Carex pachystylis. They also visit brakes of haloxylon, especially if such forests are located near the tugai. At night they often move from the tugai forests in the valley to the Kashka-Kum desert, where they find feed on the semi-consolidated sands and in haloxylon brakes. (Bobrinsky, 1933; Flyorov, 1935; Chernyshov, 1958.)

\section{Migration and Movements}

Some groups and individual animals stick to certain areas more or less permanently, although exact data relating to territorial distribution are scanty, and the size of individual territories has not been established. K. K. Flyorov (1935) observed that for several days one family kept to one area; although scared away it returned every day to the same place for a daytime rest.

The Bactrian hangul does not make regular long migrations, but moves about locally. Migration usually occurs in spring and summer when flooding of the rivers forces them to move out of the valleys (Flyorov, 1935; Klyushkin, 1949). Irregular roaming from one tugai forest to another is the result of man's activities (Mambetdgumayev, 1961). Every year deer come to the lower Pyandzh from the Afghan side when the reeds there are burned. In the last century the deer migrated almost regularly from the haloxylon forests of the northem Kizil-Kum to the tugai forests on the Syr-Darya and vice versa (Bobrinsky, 1933). A. M. Mambetdgumayev (1967) mentions an instance of two deer appearing in the lower Amu Darya (to the north of Nukus), in the snowy winter of 1964. They could have come from the tugai of Matiyaz-Jimmy (the middle Amu Darya) to the south-west, a distance of about $350 \mathrm{~km}$.

Knowledge of the Bactrian hangul's food is scanty. Their basic food is the woody, shrubby and herbaceous vegetation of low-lying lands. In winter they prefer haloxylon shoots Haloxylon sp., tamarisk Tamarix sp., fruits of the Russian olive Elaeagnus sp. and poplar leaves Populus pruinosa. In summer they also eat grass and 
saltwort Salsola sp. In the lower Vakhsh the basic feed for the deer in winter was haloxylon and tamarisk shoots, according to K. Flyorov (1935). V. I. Chernyshov (1958) said that fruits of the Russian olive and herbaceous vegetation played a considerable role as winter feed, with reed Phragmites sp., cogongrass Imperata cylindrica and Aeluropus littoralis all the year round. They seldom eat bark. S. U. Stroganov (1959) lists 94 plant species, eaten in southern Tajikistan. Approximately the same species of plants are available on the island of Aral-Paygambar (Ishunin, 1967).

Fewer food plants are available in the middle Amu Darya, according to A. M. Mambetdgumayev (1961): only 27 species are mentioned: There the animal's favourite feed is poplar leaves all the year round, also Aeluropus littoralis and in spring the desert ephemerals, especially the sand reed Carex pachystillis (Klyushkin, 1949). Sometimes during droughts they go into crops; white durra (Sorghum sp.) and cotton plant (Gossipium sp.) have been recorded.

\section{Diurnal activity and behaviour.}

Little is known about the hangul's diurnal activity. In summer and early autumn they lie up during the hot period of the day, usually in broken tugai forest or tamarisk brakes, but always near impenetrable reeds or dense scrub. In the Tigrovaya Balka reserve during floods they lie on small dry plots surrounded by flooded reed and bush grass, sometimes even lying in shallow water. In the evening, about 6.0-7.0 pm they move to open places on river or lake banks to water, and spend the greater part of the night, until 2.0 or $3.0 \mathrm{am}$, grazing. In the morning, after watering they feed again (up to 9.0 or $10.0 \mathrm{am}$ ) and then lie up again, making a total activity period in these seasons of about ten hours (Mambetdgumayev, 1961). In autumn and winter the activity cycle is about the same, except that they also graze in the daytime. In the Vakhsh area, for instance, on winter nights they go out into the desert to graze the ephemerals and haloxylon shoots; in the day they often feed in the tamarisk brakes (Flyorov, 1935; Klyushkin, 1949; Mambetdgumayev, 1961). As a rule they water at night or at dawn. They are good swimmers, swimming easily such powerful rivers as the Vakhsh and Pyandzh. 'The deer swims at a surprising speed and easily overcomes the stream', wrote $K$. K. Flyorov (1935).

At one time the deer were less timid than they are today, and would allow a man to come up as close as $60.70 \mathrm{~m}$, even closer if they were lying down; today this is only possible in the Tigrovaya Balka and Aral-Paygambar reserves. Once put up they gallop away $50-100 \mathrm{~m}$, crashing through the scrub, then slowing to a quiet trot; after $300-400 \mathrm{~m}$, they stop to listen. When running the males toss back their heads, so that the antlers nearly touch the back. K. K. Flyorov measured the jump of one frightened deer in the Vakhsh area as $5 \mathrm{~m}$ long, and this is not the limit.

The deer usually herd together in small groups. Mambetdgumayev (1961) has never seen more than seven heads in a group, but herds of 15-20 and 50-60 animals have been seen in the Tigrovaya Balka reserve, and in October 1956 over 100 animals were seen in one herd 
(Mambetdgumayev, 1961). K. K. Flyorov (1935) says, that in autumn and winter the herds increase up to 10-12 heads and remain together up to calving, when females separate from the herds and live in solitude. After calving a female lives with her calf; sometimes two females come together. About July males, which had been living separately, may join such groups.

\section{Mating}

Mating takes place in September or October, occasionally early November, according to K. K. Flyorov $(1935,1952)$, B. A. Klyushkin (1949) and Mambetdgumayev (1961). B. I. Chernyshov (1958) has observed that in 1946-1950 bellowing began in the Tigrovaya Balka reserve between August 30 and September 6 and ended between September 26 and October 5. Covering of females occurred between September 1 and October 10. In the Moscow Zoo the most intensive bellowing occurs during the first or second half of October, and at this time fighting between males occurs: in 1956 a large male was killed in this way. Most of the females were covered in the middle of October (Tsalkin, 1944). The harem which is maintained until the end of November, usually consists of two females (Stroganov, 1945), but A. M. Mambetdgumayev (1961) has observed also harems of three and five females. The gestation period is 8 months (Chernyshov, 1958), and most females produce only one calf. In the lower Vakhsh calving occurs between late April and the end of May (Flyorov, 1935; Chernyshov, 1958); in the Moscow Zoo calving occurred between mid-June and the end of July, 37 per cent being in July (Tsalkin, 1944). The exact time of puberty has not been established. Probably males become sexually mature at five to six years, and females at three to four.

Little is known about the size of the deer in the wild. A newly born calf weighs $11-13 \mathrm{~kg}$, according to V. I. Chernyshov (1958), who also says that a female caught in April 1948 weighed $156 \mathrm{~kg}$, and a male caught in August $200 \mathrm{~kg}$. Males can reach $250 \mathrm{~kg}$ (Chernyshov, 1958).

Antlers are dropped in late February or early March, and new ones are fully grown by July. When bellowing begins they are becoming clean (Chernyshov, 1958). K. K. Flyorov (1935) however says that the time of antler growth and cleaning varies considerably, and for younger animals may continue until the end of September. The antlers of a deer in the Moscow Zoo weighed $3.5-5.5 \mathrm{~kg}$ (Tsalkin, 1945). The spring moult begins in April and is completed by the end of June (K. K. Flyorov, 1935 and V. I. Tsalkin 1945). The autumn moult occurs between August and late October and the winter fur is fully grown by early December. Juveniles acquire their first winter fur by November.

\section{The Main Enemies}

Tigers and wolves are the hangul's main enemies. In the Tigrovaya Balka reserve, between 1946 and 1950, there were 19 cases of deer killed by tigers; four adult males, 12 adult females and three calves. In the 1930's tigers were the main and almost the only enemy (Flyorov, 
1935). Today there are no resident tigers, and only occasionally (1960, $1962,1964)$ do individual tigers roam the area of the lower Vakhsh and Pyandzh (Bannikov, Zhirnov, Lebedeva, 1967), but in some places wolves do considerable damage. In 1962-1963 they destroyed all the younger deer on the island of Aral-Paygambar (Southern Uzbekistan), and in 1963 several mature females and one male were killed there. Remains of deer were found in 15.3 per cent of 111 samples of wolf excrement and food remains collected in June 1963 (Ishunin, 1967). Striped hyena, jackal, jungle cat and other beasts of prey in the tugai forests also kill fawns, although no proof is available, and fawns also fall victims to sheep-dogs (Chernyshov, 1958).

\section{Floods \& Fire}

Natural calamities cause considerable losses. After the disastrous floods in 1949 in the middle Amu Darya 37 deer were found dead in the tugai forests of Darganat, and the total number destroyed was over 50 (E. A. Klyushkin 1954). Between June 1958 and March 1959, 13 deer were found in the Tigrovaya Balka in the Vakhsh area, stuck in the thick, miry silt (Mambetdgumayev, 1961). In 1958 thirteen died in the floods in the lower Vakhsh and five were saved, according to M. A. Gulyayeva (1962), who says that 'silt remains a trap for the deer for a long time if its depth exceeds $50 \mathrm{~cm}$. Fire is common in the tugai forests. Moreover, the people on the Afghan bank of the Pyandzh periodically burn out the reed, inflicting losses on the deer; some cross the river to escape, but others die. Poaching continues even in the Tigrovaya Balka reserve, despite the fact that the deer are completely protected (Mambetdgumayev, 1961).

But destruction of the habitat is the main cause of the deer's decline. The felling of the tugai forests, cattle grazing, cultivation and other forms of human activity have severely reduced their numbers. Development of the valley lands has accelerated in the last 20-30 years. In the Vakhsh valley alone (Jelikul forestry), between 1933 and 1957, the tugai forest area decreased by 1500 hectares, roughly 12 per cent. In the Kafirnigan valley and along the Kizil-Su a large area of meten-tugai forest has been irrigated and brought under the plough (Chernyshov, 1958). In the middle Amu Darya the tugai forests are being destroyed, and erosion (by the river) accelerates the process (Mambetdgumayev, 1961).

Little is known about the deer's parasites. Twelve species of tick of the Ixodidae family are known (Chernyshov, 1958, Mambetdgumayev 1961), and the ticks Boophilus calcaratus and Dermacenfor daghestanieus have been found in large quantities; Mambetdgumayev considers the Bactrian hangul to be one of the principal spreaders of these ticks.

\section{The Main Factor}

The accelerated decline of this deer's population in all areas in recent years is undoubtedly the result of the rapid economic development of the Middle-Asian republics, bringing an inflow of population and destruction of the tugai forests for cultivation and pasture. Under such conditions poaching coupled with inadequate protection could lead in the long run to the extinction of the Bokharan deer in the USSR. The 
situation calls for urgent protection and rehabilitation measures in the Tigrovaya Balka and Aral-Paygambar reserves, where good tugai forest stands with a considerable number of deer have been preserved. Research work in the reserves should be increased; occasional observations are not adequate. Experiments to acclimatise the deer in the Ramit reserve on the southern spurs of the Gissar ridge should be considered (Sinelnikov, 1964), acclimatisation experiments in Tajikistan enlarged, and perhaps also others considered in the mountain forests along the lower and middle course of the Obikhingou river, on the left bank of the Vakhsh, in the area of Komsomolabad and in other areas of the Tajikistan Mountain, where there are still good forest stands. The tugai forests along the Amu Darya and Pyanj, on the territory of the Uzbek and Taijk SSR should be thoroughly surveyed to determine the numbers, and plans made for increasing it; a similar survey in northern Afghanistan is also highly desirable.

\section{Countryside Commission}

A 16-page booklet explaining the work of the Countryside Commission and a folder on long-distance footpaths are obtainable free from Cambridge Gate, London N.W.1.

\section{Feral Goats}

UFAW's annual report for 1960/70 includes an account of the feral goats on Holy Island, Arran, by H.S. McTaggart, who has completed a two-year study, and also an account of the 1969 seal-killing in the Wash.

AN OUTSTANDINGLY IMPORTANT NEW PUBLICATION

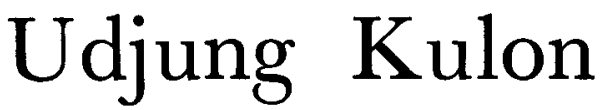

the land of the last favan Rhinoceros

\section{A. HOOGERWERF}

4to. (5I2pp., I55 illus. on 83 plates, 3 fold. maps) $£$ III.25

This monograph presents the fruit of the author's I2-year association with Udjung Kulon in Indonesia. The chief focus is on Rhinoceros sondaicus, one of the world's rarest animals, which survives only in this reserve. The material is more detailed than any previously published, and is a more comprehensive study than has appeared on any extant species of rhinoceros. There is a wealth of unique photographs. The other large Javan mammals - the banteng, Javan tiger and Javan deer - are discussed with equal thoroughness. The smaller mammals and the birds and reptiles found in the reserve are dealt with individually. A résumé is given of protective measures taken for each species discussed. There are chapters on the reserve's history, topography, geomorphology and vegetation.

Order from C. HURST (Publishers) Ltd., 40a Royal Hill, London S.E. 10, U.K. 